\title{
Surface activity of some intertidal invertebrates in relation to temperature and the foraging behaviour of their shorebird predators
}

\author{
Michael W. Pienkowski
}

Department of Zoology, University of Durham, South Road, Durham DH1 3LE, United Kingdom

\begin{abstract}
Effects of environmental conditions on the behaviour of the prey animals of Ringed and Grey Plovers Charadrius hiaticula and Pluvialis squatarola were investigated in the field at Lindisfarne National Nature Reserve, Northumberland, England. The plovers detected and caught prey by watching for, and exploiting, the brief periods of surface activity. The cues used include cast production by Arenicola marina, outflows of water from the holes of Notomastus latericeus and other polychaetes, and swimming movements by small amphipods and isopods. The intertidal polychaetes $A$. marina and $N$. latericeus, the amphipod Bathyporeja pelagica and the isopod Eurydice pulchra increased their surface activity in relation to variations in environmental conditions, particularly warmer temperatures. When activity of the surface-living small Crustacea was low, Ringed Plovers used foot-vibration to stimulate movement of these animals, making them visible.
\end{abstract}

\section{INTRODUCTION}

Coastal wetlands are among the most productive of ecosystems and hold very dense populations of invertebrates in the intertidal flats (e.g. Whittaker, 1970; Eltringham, 1971; Milne and Dunnet, 1972). Many of these invertebrates spend much of their time deep in the substrate, either because of their physiological and/or feeding requirements (e.g. Green, 1968) or to escape predation by fish and birds (cf. Evans, 1979). In the non-breeding season, large flocks of arctic-breeding shorebirds resort to temperate coastal wetlands to feed on the invertebrate fauna. The ways in which shorebirds forage, and the interrelationships with prey behaviour, have been considered by several workers (e.g. Goss-Custard, 1969, 1977; Smith and Evans, 1973; Evans, 1975, 1976; Smith, 1975; Hulscher, 1976), but all these studies concentrated on waders which forage partly by tactile means, as opposed to the plovers which apparently forage almost entirely by visual means.

The present paper quantifies the behaviour of some of the prey animals of Ringed and Grey Plovers Charadrius hiaticula L. and Pluvialis squatarola (L.), the 2 shore plovers common in winter in Europe, and considers how this varies with environmental condi- tions, particularly temperature. I argue that the plovers detected and caught prey by exploiting the brief periods of surface activity. Although the patterns of surface activity of many shore and marine invertebrates have been studied in the laboratory, the behaviour of several species differs markedly in the field (e.g. Smith, 1975 for Arenicola marina (L.); Barnes (1981) for Hydrobia ulvae (Pennant). As the field situation is obviously more relevant to a study of behavioural interactions between predator and prey, I measured prey activity directly in the field. Some complementary studies in the same area by Smith (1975) are also summarised to allow a more comprehensive assessment of predator-prey interactions. Because many other shorebird species probably depend to some extent on surface activity of prey animals, the results have wider implications than just to plovers.

Both species of plovers feed in the highly characteristic stop-run-peck manner of plovers, detecting prey visually rather than by touch (Pienkowski, 1981 a, 1983). A bird stands still for up to several seconds depending on site, weather conditions and prey type (Pienkowski, $1981 \mathrm{~b}, 1983$ ), before running rapidly to a new searching position, or to peck at a prey item. The plovers' large eyes, set well to the sides of the head, and combining a wide angle of vision with good 
binocular vision, are presumably adaptations to a specialization in visual foraging. Burton (1974) discussed how their short straight bills, large heads and related head anatomy aid rapid alignment towards a position indicated by a short-term cue, and are tolerant of hard impacts on the substrate. The detailed manner of taking particular prey species is described by Pienkowski (1982) and Pienkowski et al. (in press). The distribution in waders' bills of Herbst corpuscles, which are pressure and vibration sensors, has been described by Bolze (1968), and appears to be adapted to the birds' feeding methods (Pienkowski 1981a, 1982, 1983). In some sandpipers, which probe in the substratum and detect prey tactilely, many corpuscles are concentrated in bony pits, with openings directed towards the sources of pressure (allowing multiple layering and possibly the gathering of directional information). In the sandpiper family generally, corpuscles are found in fairly high densities spread along the outer bill. In contrast, plover bills do not have well developed pits, and show concentrations of corpuscles only at the bill tip, but inside this as well as outside. This pattern is probably adapted to surface pecking and sensitivity to precise gripping of prey as it is taken.

In the present study area, foraging Ringed Plovers sometimes vibrated one foot on the substrate surface while in a waiting position, but this was rarely done by Grey Plovers.

The ways in which foraging behaviour varied in different tidal and weather conditions are considered elsewhere (Pienkowski, 1981 b, 1983).

\section{STUDY AREA AND METHODS}

Observations were made mainly on the eastern and northern parts of Holy Island Sands, Northumberland, England (Fig. 1). This predominantly sandy area of about 750 hectares, characterised by high densities of casts formed by lugworms Arenicola marina, forms part of Lindisfarne National Nature Reserve. The sandy region was the main winter feeding area of Ringed Plovers and one of the main areas used by Grey Plovers. The main prey of both species over most of the area were the polychaetes Notomastus latericeus Sars, and, particularly for the Grey Plover, Arenicola marina, (Pienkowski, 1982).

Ringed Plovers were also watched in some sites just below the high water mark where they took small Crustacea, notably the amphipod Bathyporeia pelagica (Bate) and the isopod Eurydice pulchra Leach, as their main prey, usually when lower areas were covered by water. These sites included the areas near the small salt marsh on the south side of the Snook and on the high flats near the Sand Rig (Fig, 1).

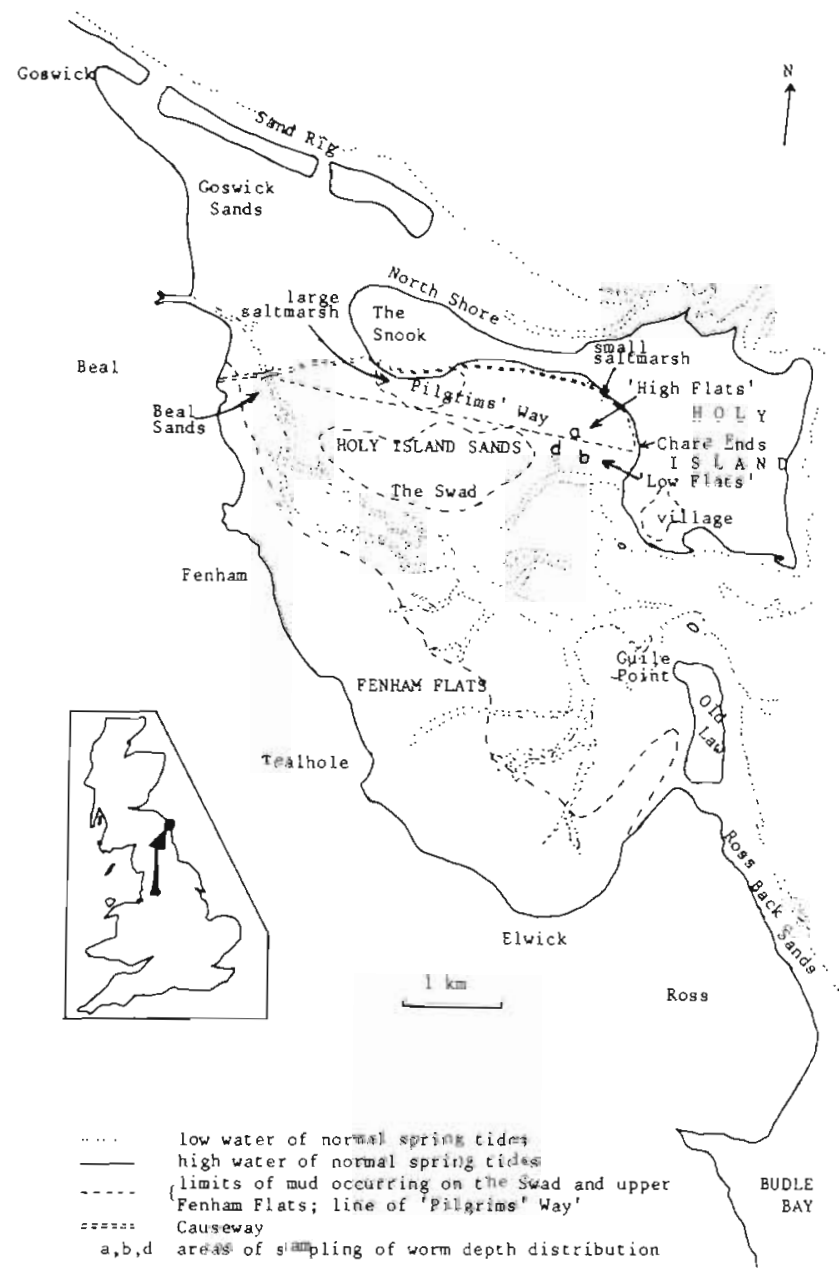

Fig. 1. Intertidal sand and mud flats at Lindisfarne, Northumberland, with inset showing location

Prey were identified from field observations of feeding birds. Pienkowski $(1982,1983)$ used ciné-film to test these methods and found them to give a valid indication of diet (whereas analysis of gut contents did not in this situation). During observation periods, records were taken of substrate temperatures at about $2 \mathrm{~cm}$ depth, wind force on the Beaufort scale, cloud by eighths of the sky covered, and rainfall on a subjective scale from 0 to 9 .

As a first step to investigate whether burrowing invertebrates were near the surface, sampling corers were pushed rapidly into the sand and removed. Samples were then divided at pre-determined depths, by metal plates pushed through slots on opposite sides of the corer. Samples were returned to a kitchen where each depth layer was sieved and sorted separately. A sieve of 20 meshes per inch (holes approximately squares of side $0.9 \mathrm{~mm}$ ) was used. Washing through a sieve of 30 meshes per inch (sides $0.5 \mathrm{~mm}$ ) took considerably longer but retained few additional animals 
Examination of the washings, through both sieves revealed no macrofauna.

On 21 February 1976, when the sand temperature was $6{ }^{\circ} \mathrm{C}$, samples were taken at about 5 -min intervals throughout the period of tidal emersion on the main study area of Holy Island Sands. Sets of five $10 \times 10 \mathrm{~cm}$ samples were taken randomly from each of 3 areas (Fig. 1), one set from Area a (just above the Pilgrims Way, a line of posts across the sand), the others from Area b ('Grey Plover Flats') and Area d ('Godwit Creek'). The surface of Area b dried more rapidly than of Area d, and Area a more rapidly than both others.

The method was not ideal, in that vertical movement of animals could occur during the sampling, even though the whole process took only a few seconds. While this may have affected the relative numbers in each layer, the method was probably sufficiently consistent to provide at least an index of changes in vertical distributions between samples.

Because of this technical problem, and the time involved in sorting samples, most effort was put into an alternative approach more directly related to the plovers' method of detecting prey, namely watching the sand surface for signs of prey activity. The general methodology was as follows. A wire quadrat was used to mark out a square of sides $10 \mathrm{~cm}$ or $50 \mathrm{~cm}$ (depending on preliminary observation to indicate the levels of activity and the area which could be watched effectively). The observer knelt and watched from about $30 \mathrm{~cm}$ height in order to count the activity signs occurring in the quadrat over a timed period. Several tests indicated that the positioning of the observer had no appreciable effect on prey activity. On the low-water feeding areas, an area of mud marked by a $10 \times 10 \mathrm{~cm}$ quadrat was watched for a period of $2 \mathrm{~min}$. Four sites were used, all in Area b on Grey Plover Flats of Holy Island Sands (which held high densities of the worms). Sites A and B were on wetter areas than Sites C and D, but worm densities were fairly similar in the 2 areas (approximately $2000 \mathrm{~m}^{-2}$ ). In order to minimize any effect of season, observations were restricted to the period between late March and early May 1976.

It will be demonstrated in the 'Results' that outflows of water from holes in the substrate surface were good indicators of the surface activity of Notomastus latericeus. On 3 occasions, the rate at which outflows occurred was investigated in relation to tidal time.

All the data on rates of outflowing were recorded on days of wind force 5 or less (i.e. less than $40 \mathrm{~km} \mathrm{~h}^{-1}$ ). Attempts were made to record worm activity at higher wind speeds, but increasing movement of any surface films of water made counting outflows impracticable. In such conditions, areas without surface water dried rapidly. In situations when the surface dried completely, so that sand particles moved if a wind blew, no outflows were apparent. This may have been because water soaked into the sand below the surface. However, it was probably due mainly to a real reduction in activity

Observations in rainy conditions were also impracticable, because the distinction between outflows and impacting raindrops was difficult to make.

The activity of small invertebrates on the high tidal level flats was investigated by watching areas enclosed by $50 \times 50 \mathrm{~cm}$ quadrats, for periods of 15 or $30 \mathrm{~s}$. These animals were not visible unless they moved. Since these high level areas were those where 'foot-vibration' by Ringed Plovers was most frequently observed (see below), after each period of observation a second observation of 15 - or 30-s. duration was made, during which a pair of forceps was vibrated on the surface of the sand, to simulate foot-vibration by the plover. Observations were made in the period late September to mid-November 1976, except those at temperatures below freezing which were made in January 1977

\section{BEHAVIOUR OF MAIN PREY SPECIES AND ITS EXPLOITATION BY PREDATORS}

The main prey animals taken by plovers on Holy Island Sands, in daylight, were Arenicola marina, Notomastus latericeus, Scoloplos armiger (O. F. Müller), Bathyporeia pelagica and Eurydice pulchra (Pienkowski, 1982). At night, probably few $A$. marina were captured, but Phyllodoce maculata (L.) was probably taken at night much more than by day (Pienkowski $1980,1982,1983)$.

\section{Notomastus latericeus and Scoloplos armiger}

Close examination of the surface of the sand in the areas where plovers were seen to take red worms (invariably head-first where observable) revealed a large number of small holes, the largest about $1 \mathrm{~mm}$ in diameter and most considerably smaller. The majority of these holes were openings of vertical burrows occupied by Notomastus latericeus, rather fewer by Scoloplos armiger, and a small number by other polychaetes, including Phyllodoce maculata, and the siphons of the bivalve molluscs Macoma balthica (L.) and Cerastoderma edule (L.).

The proportion of Notomastus latericeus near the surface (i.e. in the top $5 \mathrm{~cm}$ of sampling cores) was very variable in all areas but was, on average, twice as high in the wet Area $d$ than in the drier Area b (mean values, using the arcsine transformation, to convert percentages to values conforming to Normal Distribu- 
tion requirements, $69.3 \%$ and $34.7 \%$ respectively). This difference was highly significant $\left(\mathrm{t}_{45}=4.73, \mathrm{P}\right.$ $<0.001$ ). No tidal pattern of depth distribution was apparent during most of the period of exposure in Area $d$, but the proportion in the surface layers in Area $b$ declined somewhat during the period of emersion. In both areas, the proportion near the surface increased slightly just before tidal immersion. The last set of samples taken from Area d showed a significant increase in proportion $(90.7 \%)$ in the top $5 \mathrm{~cm}$, compared with all other samples taken during low water in the same area $(62.0 \%)\left(\mathrm{t}_{21}=2.61, \mathrm{P}<0.02\right)$. These patterns are compatible with those found by Smith (1975), who used similar sampling methods at the same site. He found that, at $4^{\circ}$ to $7^{\circ} \mathrm{C}$, the proportion of polychaetes in the top $5 \mathrm{~cm}$ was highest on the ebbtide line (55\%), next highest on the flood-tide line $(49 \%)$, then on wet areas above the tide line $(41 \%)$ and finally on drier areas (36\%). On colder days, the percentages were lower: $43 \%$ on the ebb-tide line at $2{ }^{\circ} \mathrm{C}$, and $28 \%$ on the flood-tide line at $-1{ }^{\circ} \mathrm{C}$. However, because of high variances, these differences found by Smith were not statistically significant.

As most polychaetes were found several centimetres below the surface, the presence of holes (where burrows reached the surface) was not a good indicator of the location of polychaetes at the surface, and therefore within reach of the plovers. (Bill lengths of Ringed Plovers are about $15 \mathrm{~mm}$, of Grey Plovers $30 \mathrm{~mm}$, but neither species normally probes to the depths of its bill - see Pienkowski, 1981a, 1982, 1983.)

The only other possible cues of reasonable frequency, apparent on close inspection of the sand, were outflows of water from some of the holes. (In addition, very infrequently, the heads of Notomastus latericeus showed at some holes; the anterior parts of Phyllodoce maculata extended from their holes; and Macoma balthica inhalant siphons were extended from their holes.) Although a small proportion of outflows were apparently due to $M$. balthica or Cerastoderma edule, most appeared to be associated with the presence of $N$. latericeus or Scoloplos armiger near the surface. This was investigated further by using a pair of forceps to 'peck' at 50 holes as water flowed from them, and 50 similar nearby holes from which there was no flow at that time. Sixty-eight percent of 'pecks' at outflows resulted in the capture of a polychaete, compared with only $22 \%$ at other holes $\left(\chi^{2}=21.38, P<<0.001\right)$. It is likely that plovers pecking at outflows would perform even better, because of their speed of response, better shaped extraction device (bill rather than forceps), and less clumsy handling of it. Because of the absence of other visual cues and the reliability of outflows as indicators of available polychaetes, I consider that these were the cues being used by plovers to detect
Notomastus latericeus and, to a lesser extent, some other prey.

As plovers appear to use visual, rather than tactile, foraging methods (Pienkowski, 1980, 1981a, 1983), further investigations of invertebrate availability used measures of these presumed visual cues - the outflows of water - rather than samples of the substrate, to indicate the densities of available prey.

At all sites, the number of outflows observed in 2min periods increased significantly with increasing temperature (Fig. 2). The difference in slopes of the regression lines between Sites $\mathrm{A} / \mathrm{B}$ and $\mathrm{C} / \mathrm{D}$ were presumably due to local conditions. Pienkowski (1980) detailed the activity patterns of outflows in relation to time of tidal exposure. There was considerable variation within and between samples, and any pattern of activity in relation to time of exposure was far less clear than the relationship with temperature.

\section{Arenicola marina}

The other main polychaete prey of plovers, especially of the larger species Grey Plover, was Arenicola marina. My observations suggested that Grey Plovers

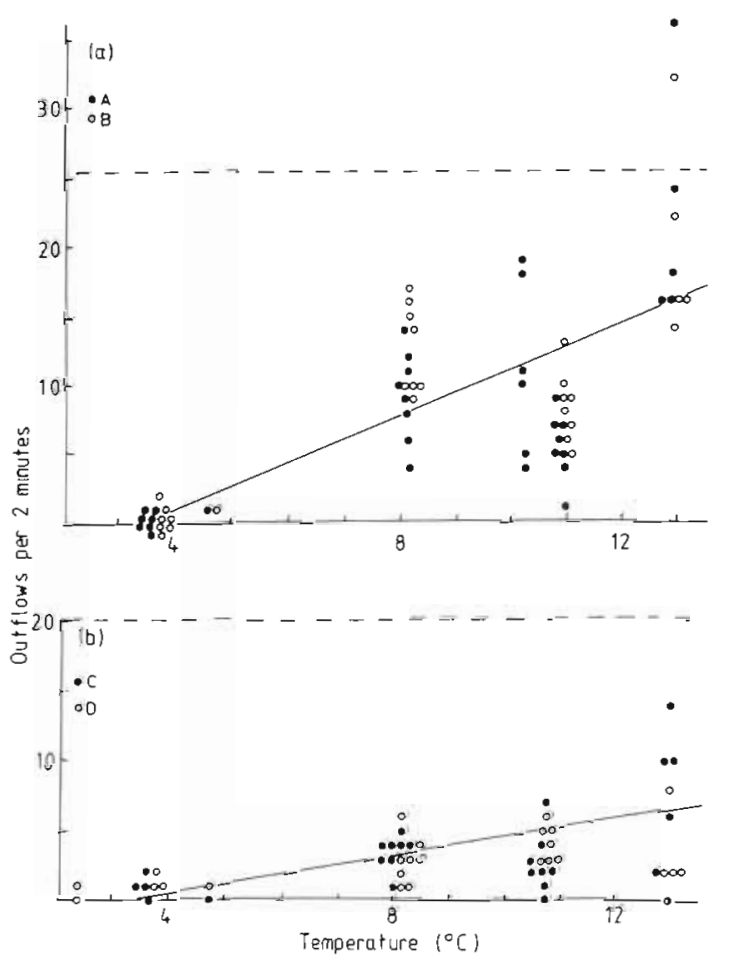

Fig. 2. Outflows $2 \mathrm{~min}^{-1}$ from holes in sand surface (see text) in $100 \mathrm{~cm}^{2}$ areas, in relation to sand temperature. (a) Sites $A$ and $B,(b)$ Sites $C$ and D. Fitted regression lines: (a) $y=1.69 x$ $-5.82, P<0.001$; (b) $y=0.67 x-2.2, P<0.01$. Dashed lines: estimated numbers of outflows which would be produced if all worms present in the sampling areas produced 1 outflow during observation 
reacted to the formation of the very obvious casts of $A$. marina; $75 \%$ of $A$. marina were taken tail first (Pienkowski, 1980). (Because of the worm's distinctive shape, it was usually easy to see which end was extracted first from the burrow.) In some cases, only the tails of $A$. marina were taken. These were clearly distinguishable from whole small $A$. marina, as the latter showed the characteristic wide anterior and narrow posterior parts while the former were very wide in relation to their length.

The behaviour of Arenicola marina in this area was detailed by Smith (1975). As his report is not published, Smith's results are summarised below. $A$. marina usually lies at a depth of about 20 to $30 \mathrm{~cm}$, but up to twice that depth in freezing conditions, in the horizontal gallery of its $\mathrm{U}$ - or L-shaped burrow. It makes excursions to the head shaft to feed, and to the surface of the tail shaft to defaecate. Smith (1975) found that the rate of cast formation by $A$. marina increased approximately linearly, from $-1{ }^{\circ} \mathrm{C}$ (below which no casts were formed) to $3^{\circ} \mathrm{C}$, above which temperature the rate remained constant. At all temperatures, the rate was somewhat higher on the falling tide than on the rising tide. On the flooding tide, a higher proportion of casts occurred near the tide edge than on the ebb. (The tide edge was defined as the area covered by up to about $15 \mathrm{~cm}$ of water together with, on the ebb, that region above the edge retaining a thin layer of water and, on the flood, that region in which the rising water table reached the horizontal galleries.) On the flood tide, the proportion of casts occurring near the tide edge increased markedly at temperatures below $3{ }^{\circ} \mathrm{C}$. The period between defaecations of individual $A$. marina increased progressively with time after exposure of the substrate, and was longer in drier areas than wetter ones, and on windy days than calm ones (Smith, 1975; Evans, 1979).

\section{Crustacea and other invertebrates on the high flats}

On the Sand Rig feeding site used by Ringed Plovers, no activity of any invertebrates was apparent at $4^{\circ} \mathrm{C}$, but some at $13^{\circ} \mathrm{C}$ and more at $17^{\circ} \mathrm{C}$ (Fig. 3 a). In both of the warm conditions, significantly more animals were seen during 'vibrations' than without. Almost all animals seen were the isopod Eurydice pulchra.

On the high parts of Holy Island Sands, a similar pattern of activity in relation to temperature was found (Fig. 3 b), no Crustacea being visible at $-1.5^{\circ} \mathrm{C}$, few at $4^{\circ} \mathrm{C}$ and more at $13^{\circ} \mathrm{C}$ and $17^{\circ} \mathrm{C}$. At $4^{\circ} \mathrm{C}$ and $13^{\circ} \mathrm{C}$, significantly more animals, about half of which were the amphipod Bathyporeia pelagica and half Eurydice

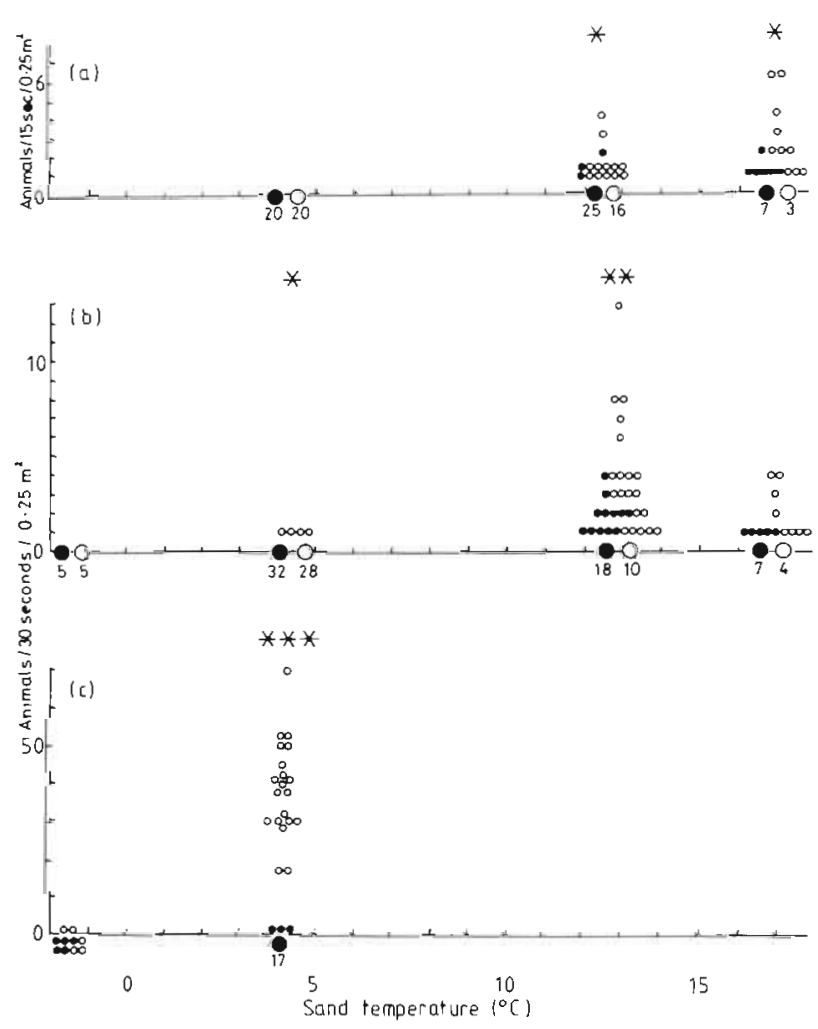

Fig. 3. Small prey observed in relation to temperature and vibration. (a) Eurydice pulchra and Bathyporeia pelagica near Rig; (b) these small crustaceans near small salt marsh; (c) very small worms near small salt marsh. O with vibration, $\bullet$ without vibration (large circles represent numbers of points indicated below them). Significant differences between with-vibration

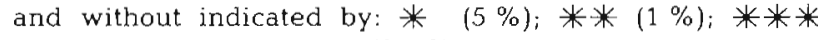
$(0.1 \%)$

pulchra, were seen during vibrations than without. At $17^{\circ} \mathrm{C}$ also, more were visible during vibrations, but the difference was not significant. At $-1.5^{\circ} \mathrm{C}$, the only animals visible were 2 very small, thin nematode worms (less than $4 \mathrm{~mm}$ long), which apparently moved in response to vibration. At $4{ }^{\circ} \mathrm{C}$, many more of these worms were seen, almost all during vibrations (Fig. 3c). These worms became visible only in the immediate vicinity of (less than $1 \mathrm{~cm}$ from) the vibrating tip of the forceps. As plovers normally peck further from their feet than this and did not concentrate their pecks in this immediate area, it is doubtful that these were taken by feeding plovers. Therefore, these worms were not studied further, and their activity was not investigated at higher temperatures.

\section{Foot-vibration by foraging plovers}

Foot-vibration while foraging has often been reported in plovers (e.g. Simmons, 1961). In this behaviour, the bird stands on one leg, with the toes of 
the other just in contact with the ground and vibrating rapidly. At Lindisfarne, this was recorded on only one occasion in Grey Plovers: a bird feeding in November near the small salt marsh, an area not much used by this species.

However, foot vibration by Ringed Plovers was recorded commonly on the highest intertidal areas where small Crustacea were the main prey: near the small salt marsh, the North Shore, and the Sand Rig, but infrequently on the lower areas of the flats, where most of the prey were polychaetes (Table 1). Usually, in any one flock, some birds used foot-vibration while others did not. On none of the high-level areas was a significant difference found in pecking rate between birds foot-vibrating and those not (Table 2). However, when the environmental conditions during observations when foot-vibration was seen are compared with those during observations without (Table 3), foot-vibration occurred at significantly lower mean temperatures on the North Shore. The same relationship was found on the high flats near the Rig, but this was not significant, probably due to small sample size. A significant temperature difference between observations with and without foot-vibration was not found on the high flats near the small salt marsh, but the behaviour there was associated with stronger winds and heavier rain.
Table 1. Occurrence of foot-vibration in feeding, fully grown Ringed Plovers in relation to location. Each observation lasted ca. 2 min

\begin{tabular}{|lcc|}
\hline $\begin{array}{c}\text { Location } \\
\text { (see Fig. 1) }\end{array}$ & $\begin{array}{c}\text { Total number } \\
\text { of obser- } \\
\text { vations }\end{array}$ & $\begin{array}{c}\% \text { occurrence } \\
\text { of foot- } \\
\text { vibration }\end{array}$ \\
\hline Sand Rig & 24 & $67 \%$ \\
Teal Hole & 14 & $57 \%$ \\
Near small salt marsh & 85 & $40 \%$ \\
North Shore & 188 & $19 \%$ \\
Inner OId Law & 28 & $4 \%$ \\
Low Flats & 194 & $4 \%$ \\
Elswhere on & 19 & $0 \%$ \\
Holy Island Sands & 21 & $0 \%$ \\
Guile Pt. \& & \multicolumn{2}{|c}{$18 \%$} \\
All ars Back Sands & 573 & \\
Sites where small crustaceans are known to be abundant \\
\hline
\end{tabular}

\section{Activity of prey animals at night}

Despite their apparent reliance on visual searching, plovers appear to be remarkably effective nocturnal hunters (Pienkowski, 1981 a, 1982, 1983).

Table 2. Mean rates of pecking by Ringed Plovers in relation to foot vibration. Given is mean number of pecks min ${ }^{-1} \pm \mathrm{S}$.E. (sample size). Data from selected sites and months are presented to allow as much standardization of conditions as possible between birds foot-vibrating and those not

\begin{tabular}{llccc|}
\hline Location & Month & $\begin{array}{c}\text { Birds foot-vibrating } \\
\text { for some or all time }\end{array}$ & $\begin{array}{c}\text { Birds not } \\
\text { foot-vibrating }\end{array}$ & $\begin{array}{c}\text { Statistical signifi- } \\
\text { cance of difference }\end{array}$ \\
\hline North Shore and Rig & April & $19.4 \pm 1.3(37)$ & $19.7 \pm 1.8(43)$ & ns \\
Near small salt marsh & April & $24.3 \pm 2.0(15)$ & $25.8 \pm 3.6(2)$ & ns \\
Tealhole & June & $16.6 \pm 3.0(8)$ & $17.1 \pm 2.9(6)$ & ns \\
\hline
\end{tabular}

Table 3. Mean environmental conditions during observation of Ringed Plovers in relation to foot-vibratıon. Mean \pm standard error (sample size). This analysis considers areas where foot-vibration was used by some birds on any day of observation. Each short period (about $2 \mathrm{~min}$ ) of observation of a bird and the associated weather conditions are taken as units of data. These units are then grouped as to whether or not the bird used foot-vibration for any part of the 2-min period. The weather conditions in these 2 categories are then compared. This should indicate if foot-shaking behaviour was more likely to be used in certain weather conditions than others

\begin{tabular}{|lccc|}
\hline Location, condition & $\begin{array}{c}\text { Observations when birds } \\
\text { were foot-vibrating for } \\
\text { some or all time }\end{array}$ & $\begin{array}{c}\text { Observations when } \\
\text { birds were not } \\
\text { foot-vibrating }\end{array}$ & $\begin{array}{c}\text { Statistical significance } \\
\text { of difference }\end{array}$ \\
\hline $\begin{array}{l}\text { North Shore } \\
\text { Air temperature }\left({ }^{\circ} \mathrm{C}\right)\end{array}$ & $10.4 \pm 0.8(32)$ & $14.7 \pm 0.4(141)$ & $\mathrm{P}<0.001$ \\
High Flats near Rig & $11.2 \pm 1.1(20)$ & $15.5 \pm 4.9(4)$ & $n$ \\
Air temperature $\left({ }^{\circ} \mathrm{C}\right)$ & $5.3 \pm 0.2(34)$ & $5.7 \pm 0.7(40)$ & $3.7 \pm 0.3(52)$ \\
High Flats near small salt marsh & $4.8 \pm 0.5(34)$ & $0.2 \pm 0.1(52)$ & $\mathrm{ns}<0.05$ \\
Air temperature $\left({ }^{\circ} \mathrm{C}\right)$ & $0.9 \pm 0.3(34)$ & $\mathrm{P}<0.05$ \\
Wind force (Beaufort scale) & & \\
Rain fall (see 'Methods') & & \\
\hline
\end{tabular}


Unfortunately, few night observations of prey behaviour were made. On one occasion, when the temperature was about $10^{\circ} \mathrm{C}$ and the sky overcast both before and after dusk, the mean number of outflows from worm holes in the flats seen in each 2 -min period was similar in daylight and at night ( $t=0.897$, n.s.). However, at night, Phyllodoce maculata emerged from the sand to a length of several centimetres and fed in water-filled hollows. Such emergences were rarely observed in daytime. At night, during 252 -min observation periods on $100 \mathrm{~cm}^{2}$ areas, 1 P. maculata was seen in each of 2 areas, and 3 in a third. The worms remained active throughout the nocturnal observation periods, and later checks showed that they were still active on the surface about 30 min later. Thus, unlike Notomastus latericeus, $P$. maculata remained on the surface; also they appeared unaffected by torch-light. Small sections of some of the $P$. maculata were luminous, apparently because of the presence in their guts of dinoflagellates. These are common on the mud surface and luminesce when disturbed.

\section{DISCUSSION}

The rate of prey capture by plovers is depressed markedly at low temperatures (Pienkowski, 1981 a,b, in prep.). Clearly, this is associated with the depression of activity of their prey (Arenicola marina, Notomastus latericeus, other polychaetes and small Crustacea) in such conditions. Activity leads prey animals to come within reach of a bird's bill and also, in some cases at least, makes them detectable. This latter point is probably applicable to a wide range of predatory situations; for example, the passerine bird Spotted Flycatcher Muscicapa striata Pallas, may lose sight of flies when the latter stop moving (Davies, 1977). Depression of activity, with declining temperature, is widely known in poikilotherms. Examples for intertidal animals, in laboratory studies, include swimming by Bathyporeia pilosa Lindström and B. pelagica (Fincham, 1970b; Preece, 1971), Eurydice pulchra (Jones and Naylor, 1970) and Corophium volutator (Pallas) (Morgan, 1965). Despite the widespread nature of such behaviours and their importance in studies of predation, quantitative studies in the field seem surprisingly few. Apart from the present studies and those of Smith (1975) summarised above, reports include emergence from the mud by antennae of $C$. volutator (Goss-Custard, 1969); and possibly siphon emergence from the mud by Macoma balthica (Goss-Custard et al., 1977).

In addition to reducing activity at low temperatures, many animals burrow deeper in the substrate in winter (e.g. Arenicola marina-Smith, 1975; Macoma balthica - Reading and McGrorty, 1978; Nereis diversicolor
O. F. Müller - Evans, 1979), or move downshore towards the sublittoral zone (e.g. A. marina, Carcinus maenas (L.), Crangon vulgaris (L.), Nerine cirratulus Della Chiaje - Brady, 1943; Naylor, 1963; Swennen, 1971; Brearey, in Evans, 1979), and this probably exacerbates the problems for shorebirds in winter. Many invertebrates also move deeper, or become less active, as the tide falls and the substrate dries (Newell, 1962; Vader, 1964; Smith, 1975; Evans, 1976, 1979; Little and Nix, 1976, present study), and this probably accounts for the general decline in feeding rates with time after exposure and increasing wind force (Pienkowski, 1980, $1981 \mathrm{~b}$, in prep.).

The problems are probably less severe for shorebirds which include in their foraging an element of tactile detection of prey at depth, e.g. many of the Scolopacidae (sandpipers); Smith (1975) considered that Bar-tailed Godwits Limosa lapponica (L.) at Lindisfarne detected small polychaetes in this way by probing in the substrate. The Charadriidae (plovers) generally do not use tactile prey detection and therefore are more reliant on surface activity of prey animals. Surface activity of the small polychaetes at Lindisfarne was more sensitive to temperature changes than depth distribution (Pienkowski, 1981a). Furthermore, particularly in cold weather, tactilely foraging shorebirds may concentrate their activity near the tide edge, where prey are generally most active, and available. This applies to Bar-tailed Godwits at Lindisfarne (Smith and Evans, 1973; Smith, 1975). For plovers, this is inappropriate because their visual foraging technique is space-demanding and is interfered with at high densities of plovers or other shorebirds (Pienkowski 1980, 1981a, 1983). At Lindisfarne, both species of plovers generally fed while in loose flocks, with individuals separated by about $1 / 2 \mathrm{~m}$ to over $50 \mathrm{~m}$. With a few exceptions, the plovers fed away from the water's edge, often spreading over much of the exposed intertidal sands. Areas where the surface had dried completely were, however, generally avoided, especially if wind started to blow the sand, as might be expected due to the lack of surface activity of prey in such areas.

Why should the prey animals make themselves available to birds at any time? Most intertidal infauna require access to the surface for food, respiration or other reasons, and burrowing is energetically expensive (Trevor, 1978). Therefore, it is probably advantageous to remain as close to the surface as conditions of temperature or predation allow, but to keep visits to the surface as brief and infrequent as possible. Indeed, despite the throughput of large quantities of sand and its removal from the burrow required by the feeding method of Arenicola marina, these polychaetes appear to be able to achieve this in a short time on each 
occasion. Furthermore, they may have to defaecate on only 2 to 5 occasions during each period of tidal exposure (Smith, 1975; Evans, 1979)

It is not clear why Notomastus latericeus makes its migrations to the mud surface, as this behaviour does not appear to have been described or investigated previously. A very few occasions of appearance of the head of the worm may have been associated with feeding, but whether the outflows result from irrigation for feeding or respiratory purposes is unknown. The mainly nocturnal surface appearances (usually in areas with a thin water covering) of other worms, such as Phyllodoce maculata, and the occasional appearances of siphons of Macoma balthica and Cerastoderma edule (also usually in areas with a water covering) appear to be associated with feeding.

It is the brief visits to the surface by polychaetes, such as Arenicola marina and Notomastus latericeus, that plovers exploit, both to locate and to reach the polychaetes. Smith (1975) showed that Bar-tailed Godwits, when preying upon $A$. marina, their main food at Lindisfarne, use a similar visual technique by responding to the cue of cast-formation by these large polychaetes. Nearly all such A. marina were thus taken tail-first. Therefore, the $25 \%$ taken head-first by the Grey Plovers in my study represents a much higher proportion taken in this manner than by godwits. This may reflect a greater sensitivity, to more subtle cues, by the large-eyed plovers, or a speedier reaction, to the presumably brief periods of availability of prey in the head shaft. Both of these possibilities accord with the morphological (Burton, 1974) and behavioural (Pienkowski, 1983) specializations of plovers as visual foragers. By specializing in scanning a large area (up to about $1 \mathrm{~m}^{2}$ at any one time for Grey Plover; Pienkowski, 1983), and being adapted to rapid movement to the site of a cue, the plovers are able to utilize a feeding area even if the density of available prey is low. The plovers' large eyes are probably adaptations which enable these birds to exploit the nocturnal activity of worms such as Phyllodoce maculata and sandhoppers such as Talitrus saltator (Montagu). These animals are presumably adapted to be active at night to avoid other, more numerous but less specialised, predators.

Small amphipods and isopods, notably Bathyporeia pelagica and Eurydice pulchra, normally swim mainly when covered by the tide, and this activity is generally related to feeding (particularly in E. pulchra, which preys on $B$. pelagica), and the achieving of mating contacts (Fincham, 1970a, b; Jones and Naylor, 1970; Preece, 1971). As in the present field study, Preece (1971) found that swimming activity, in the laboratory, was depressed at low temperatures. Most of these authors found a tidal rhythm which could be modified by environmental conditions. In laboratory studies, Enright $(1962,1965)$ found that activities of several intertidal amphipods were stimulated by rapid, but small, changes in hydrostatic pressure, and suggested that this was an adaptation to initiate swimming when waves reach the animals, as the tide rises or falls. Also in the laboratory, Jones and Naylor (1970) found that only mechanical disturbance of the sand caused Eurydice pulchra to swim, and concluded that it seems likely that in the field wave action must wash them out'.

The foot-vibration of Ringed Plovers is probably exploiting this reaction to vibrations and stirring, as the plovers used this method commonly only in the areas where these small Crustacea were prey, and the method was used most commonly when the birds were feeding on the Sand Rig area, where almost all prey were Eurydice pulchra. There was no difference in feeding rates in a given area between birds foot-shaking and those not, but this could be because Ringed Plovers foot-vibrate only when prey are being detected insufficiently quickly without vibration. This is supported by Table 3 , which shows that foot-vibration was frequently associated with environmental factors tending to reduce prey activity or feeding rate. It is also possible that at high temperatures, most prey present are active without foot-vibration (Fig. 3 ).

Like other aspects of plovers' behaviour, foot-vibration is clearly not adapted solely to particular prey types (Pienkowski, 1981a, b, 1982). Simmons (1961), Sparks (1961) and Swennen and van der Baan (1959) have described and reviewed some of the occurrences of the various types of foot movement in plovers and other birds. Some plovers use a similar technique in a very different terrestrial situation of feeding on earthworms Lumbricus spp. and Allolobophora spp. It has been suggested (without strong evidence) that the earthworms react to the vibrations as if they were caused by rain, and emerge from their burrows; also that similar vibrations are caused by moles Talpa europeaea L., and the worms ascend to avoid falling into mole tunnels (Simmons, 1961). It seems likely that the foot-vibration technique may be applied by the plovers in any situation, its use being continued if profitable. The occasional - and unmaintained occurrence of foot-vibration on the low tidal flats of Holy Island Sands would be compatible with this interpretation. In the present study in an intertidal situation, foot-vibration was not used where worms were the main prey. This is in agreement with the observations of Swennen and van der Baan (1959) and Sparks (1961), but contrary to the suppositions of Simmons (1961). As suggested by Sparks, foot-vibration is used when small Crustacea are the main prey, although the way in which it makes them more avail- 
able appears to depend at least partly on the animals normal reaction to waves and tide, rather than only (as Sparks supposed) by producing a semi-fluid water/ sand mixture by thixotropy, thus causing the animal to swim.

Acknowledgements. I am grateful to Dr. P. R. Evans for advice and encouragement; also to other colleagues at Durham, particularly Dr. N. C. Davidson, Dr P. J. Dugan, Dr. A. V Millard, Dr. P. C. Smith and Dr. D. J. Townshend for information and discussions; and to my wife, Ann, for help throughout the work. The Nature Conservancy Council allowed study on the Lindisfarne National Nature Reserve, where help was kindly given by M. J. Hudson (Regional Officer), E. F. Pithers (Chief Warden) and D. O'Connor (Warden). I thank Dr. P. Garwood (University of Newcastle) for confirmation of the identification of polychaetes; and G. H. Green and Dr. F. Kurrein for translations of literature. I am grateful to the Research and Special Publications Fund of the British Ornithologists' Union for financial support; and to Dr. R. H. Drent, Dr. P. R. Evans and Dr. C. M. Perrins for comments on an earlier draft of this paper.

\section{LITERATURE CITED}

Barnes, R. K. S. (1981). Behavioural activities and ecological strategies in the intertidal gastropod Hydrobia ulvae. In: Jones, N. V., Wolff, W. J. (eds.) Marine science 15, Feeding and survival strategies of estuarine organisms. Plenum Press, New York, p. 79-90

Bolze, G. (1968). Anordnung und Bau der Herbstschen Körperchen in Limicolenschnäbeln im Zusammenhang mit der Nahrungsfindung. Zool. Anz. 181: 313-355

Brady, F. (1943). The distribution of the fauna of some intertidal sands and muds on the Northumberland coast. J. Anim. Ecol. 12: 27-41

Burton, P. J. K. (1974). Feeding and the feeding apparatus in Waders. Brit. Mus. (Nat. Hist.), London

Davies, N. B. (1977). Prey selection and the search strategy of the Spotted Flycatcher (Muscicapa striata) in a field study on optimal foraging. Anim. Behav. 25: 1016-1033

Eltringham, S. K. (1971). Life in mud and sand. English University Press, London

Enright, J. T (1962). Responses of an amphipod to pressure changes. Comp. Biochem. Physiol. 7: 131-145

Enright, J. T. (1965). Entrainment of a tidal rhythm. Science, N.Y. $147: 864-867$

Evans, P. R. (1975). Notes on the feeding of waders on Heron Island. Sumbird 6: 25-30

Evans, P. R. (1976). Energy balance and optimal foraging strategies in shorebirds: some implication for their distributions and movements in the non-breeding season. Ardea 64: 117-139

Evans, P. R. (1979). Adaptations shown by foraging shorebirds to cyclical variations in the activity and availability of their intertidal prey. In: Naylor, E., Hartnoll, R. G. (eds.) Cyclic phenomena in marine plants and animals. Pergamon Press, Oxford \& New York, p. 357-366

Fincham, A. A. (1970a). Amphipods in the surf plankton. J. mar. biol. Ass. U.K. 50: 177-198

Fincham, A. A. (1970b). Rhythmic behaviour of the intertidal amphipod Bathyporeia pelagica. J. mar. biol. Ass. U.K. 50: $1057-1068$

Goss-Custard, J. D. (1969). The winter feeding ecology of the Redshank Tringa totanus. Ibis 111: 338-356
Goss-Custard, J. D. (1977). Optimal foraging and the size selection of worms by Redshank, Tringa totanus, in the field. Anim. Behav. 25: 10-29

Goss-Custard, J. D., Jenyon, R. A., Jones, R. E., Newbery, P E., Williams, R. le B. (1977). The ecology of the Wash. II. Seasonal variation in the feeding conditions of wading birds (Charadrii). J. appl. Ecol. 14: 701-719

Green, J. (1968). The biology of estuarine animals. Sidgwick and Jackson, London

Hulscher, J. B. (1976). Localisation of cockles (Cardium edule L.) by the oystercatcher (Haematopus ostralegus L.) in darkness and daylight. Ardea $64: 292-310$

Jones, D. A., Naylor, E. (1970). The swimming rhythm of the sandbeach isopod Eurydice pulchra. J. exp. mar. Biol. Ecol. 4: 188-199

Little, C., Nix, W. (1976). The burrowing and floating behaviour of the gastropod Hydrobia ulvae. Estuar. coast. mar. Sci. 4: $537-543$

Milne, H., Dunnet, G. M. (1972). Standing crop, productivity and trophic relations of the fauna of the Ythan Estuary. In: Barnes, R. S. K., Green, J. (eds.) The estuarine environment. Applied Science Publishers, London, p. 86-106

Morgan, E. (1965). The activity rhythm of the amphipod Corophium volutator Pallas and its possible relationship to changes in hydrostatic pressure associated with the tides. J. Anim. Ecol. 34: 731-746

Naylor, E. (1963). Temperature relationships of the locomotor rhythm of Carcinus. J. exp. Biol. 40: 669-679

Newell, R. C. (1962). Behavioural aspects of the ecology of Peringia (= Hydrobia) ulvae (Pennant). Proc. zool. Soc. Lond. 138: 49-75

Pienkowski, M. W. (1980). Aspects of the ecology and behaviour of Ringed and Grey Plovers Charadrius hiaticula and Pluvialis squatarola. Ph. D. thesis, University of Durham

Pienkowski, M. W. (1981a). Differences in habitat requirements and distribution patterns of plovers and sandpipers as investigated by studies of feeding behaviour. Proc. IWRB Feeding Ecology Symp, Gwatt, Switzerland, Sept. 1977. Verh. orn. Ges. Bayern 23: 105-124

Pienkowski, M. W. (1981b). How foraging plovers cope with environmental effects on invertebrate behaviour and availability. In: Jones, N. V., Wolff, W. J. (eds.) Feeding and survival strategies of estuarine organisms. Plenum Press, New York, p. 179-182

Pienkowski, M. W. (1982). Diet and energy intake of Grey and Ringed Plovers, Pluvialis squatarola and Charadrius hiaticula, in the non-breeding season. J. Zool., Lond. 197: 511-549

Pienkowski, M. W. (1983), Changes in the foraging pattern of plovers in relation to environmental factors. Anim. Behav. 31: $244-264$

Pienkowski, M. W., Ferns, P. N., Davidson, N. C., Worrall, D. $H$. (in press). Balancing the budget: problems in measuring the energy intake and requirements of shorebirds in the field. In: Evans, P. R., Goss-Custard, J. D., Hale, W. G. (eds.) Coastal waders and wildfowl in winter. Cambridge University Press, Cambridge

Preece, G. S. (1971). The swimming rhythm of Bathyporeia pilosa (Crustacea: Amphipoda). J. mar. biol. Ass. U.K. 51 : $777-791$

Reading, C. J., McGrorty, S. (1978). Seasonal variations in the burying depth of Macoma balthica (L.) and its accessibility to wading birds. Estuar, coast. mar. Sci. 6: 135-144

Simmons, K. E. L. (1961). Foot-movements in plovers and other birds. Br. Birds 54: 34-39 
Smith, P. C. (1975). A study of the winter feeding ecology and behaviour of the Bar-tailed Godwit (Limosa lapponica). Unpublished Ph. D. thesis, University of Durham

Smith, P. C. Evans, P. R. (1973). Studies of shorebirds at Lindisfarne, Northumberland. 1. Feeding, ecology and behaviour of the Bar-tailed Godwit. Wildfowl 24: 135-139

Sparks, J. H. (1961). The relationship between foot-movements and feeding in shorebirds. Br Birds 54: 337-340

Swennen, C. (1971). Het voedsel van de Groenpootruiter Tringa nebularia tijdens het nerblijf in het Nederlandse Waddengebied. Limosa 44: 71-83
Swennen, C., van der Baan, G. (1959). Tracking birds on tidal flats and beaches. Br. Birds 52: 15-18

Trevor, J. H. (1978). The dynamics and mechanical energy expenditure of the polychaetes Nephtys cirrosa, Nereis diversicolor and Arenicola marina during burrowing. Estuar coast. mar. Sci. 6: 605-619

Vader, W. J. M. (1964). A preliminary investigation into the reactions of the infauna of the tidal flats to tidal fluctuations in water level. Neth. J. Sea Res. 2: 189-222

Whittaker, R. H. (1970). Communities and ecosystems. Macmillan, London

This paper was submitted to the editor; it was accepted for printing on November 29,1982 